\title{
Human Genetics Studies: The Case for Group Rights
}

\section{Laura S. Underkuffler}

\section{Introduction}

During the past twenty years, the importance of human genetic information has exploded. Whether sought for medical treatment, disease prediction studies, cultural studies, or the general study of human origins, human genetic information is now viewed as crucial for scientific research and general attempts at human understanding.

With the importance of genetic information has come bitter battles over its control. The demonstrated power of human genetic information has moved the issue of its “ownership” from the realm of musty academic musings to protracted political and legal battles among "source” individuals, researchers, commercial concerns, government agencies, and others. Whether collected through targeted scientific studies, ${ }^{1}$ “discarded” biological tissue, ${ }^{2}$ initial charitable

${ }^{1}$ See, e.g., J. Barker, “The Human Genome Diversity Project: 'Peoples’, ‘populations’, and the cultural politics of identification,” Cultural Studies 8 (2004): 571-606, at 595 (discussing studies).

${ }^{2}$ See, e.g., Moore v. Regents of the University of California, 793 P.2d 479 (Cal. 1990), cert. denied, 499 U.S. 936 (1991). 
bequest, ${ }^{3}$ or other means, genetic information and the biological materials in which it is contained have become the subject of protracted legal battles for control and intense social and ethical controversy.

In these battles, some principles have emerged that are beyond dispute. Most fundamentally, the ability of individuals to control the disposition and genetic testing of their own biological materials is (as a matter of theory, at least) beyond question. No one would argue today that an individual could be subject to genetic testing for studies against her will, or that biological samples obtained from individuals under specified conditions could be simply deemed "free" of such conditions by researchers. Although difficult problems remain in the interpretation of research agreements, the circumstances under which "informed consent" was given, and so on, the general principle that individuals have a right to control the genetic testing of their own biological materials is assumed by ethicists, medical researchers, and others. It is also assumed (through contract, property, and privacy theories) by law.

Far more contested is the idea of group control over the collection, testing, and disposition of the biological materials of its members. When - for instance - isolated indigenous populations are chosen for genetic study in an effort to "grasp ... human origins, evolution, prehistory, and potential," ${ }^{4}$ or patented cell lines are made from blood samples collected from indigenous peoples, ${ }^{5}$ affected groups have demanded control of such projects citing an invasion

${ }^{3}$ See, e.g., Greenberg v. Miami Children's Hospital, 264 F. Supp. 2d 1064 (S.D. Fla. 2003) (donation of biological samples for Canavan disease research).

${ }^{4}$ L. Cavalli-Sforza et.al., "Call for a Worldwide Survey of Human Genetic Diversity: A Vanishing Opportunity for the Human Genome Project," Genomics 11 (1991): 490-491, at 491.

${ }^{5}$ See, e.g., Barker, supra note 1, at 595; A. Bhat, "The National Institutes of Health and the Papua New Guinea Cell Line,” Cultural Survival Quarterly 20 (1996): 29-31. For discussion 
of sovereignty, lack of informed consent, and moral grounds. ${ }^{6}$ However, group demands for effective control or "veto power" have, however, been met with skepticism or outright rejection by many researchers, ethicists, and legal scholars. ${ }^{7}$ The stated reasons for this response are multifarious, and include representational conundrums (who is “the group”?), ${ }^{8}$ practical problems (how do we handle "dispersed communities”?), ${ }^{9}$ ethical questions, ${ }^{10}$ and resource issues. ${ }^{11}$ In addition, when the demanding groups are indigenous peoples, acknowledging

of the legal and ethical issues involved in such patenting projects, see L. Demaine and A. Fellmeth, "Reinventing the Double Helix: A Novel and Nonobvious Reconceptualization of the Biotechnology Patent," Stanford Law Review 55 (2002): 303- 462; M. Whelan, "What, if Any, Are the Ethical Obligations of the U.S. Patent Office? A Closer Look at the Biological Sampling of Indigenous Groups,” Duke Law and Technology Review (2006):

${ }^{6}$ See D. Harry, "The Human Genome Diversity Project: Implications for Indigenous Peoples," Abya Yala News 8 (1993): 13-15, at 14; A. Mead, "Genealogy, Sacredness, and the Commodities Market,”Cultural Survival Quarterly 20 (1996): 46-52, at 46-48.

${ }^{7}$ See, e.g., E. Juengst, “Groups as Gatekeepers to Genomic Research: Conceptually Confusing, Morally Hazardous, and Practically Useless," Kennedy Institute of Ethics Journal 8 (1998): 183-200; National Research Council, Evaluating Human Genetic Diversity (Washington, D.C.: National Academy Press,1997), at . For a different view, see H. Greely, "Genes, Patents, and Indigenous Peoples: Biomedical Research and Indigenous Peoples’ Rights,” Cultural Survival Quarterly 20 (1996): 54-59, at 57 (advocating an approach under which "the decision whether and what terms a population will participate in genetic research belongs to the group").

${ }^{8}$ See, e.g., Juengst, supra note 7, at 187 (contrasting genetic populations and "selfidentified, morally authoritative social groups"); R. Sharp and M. Foster, "Involving Study Populations in the Review of Genetic Research," The Journal of Law, Wedicine and Ethics 28 (2000): 41-51, at 47 (describing the problem of the "nesting" of local and larger communities).

${ }^{9}$ See, e.g., Sharp and Foster, supra note 8, at 47-48.

${ }^{10}$ See, e.g., Juengst, supra note 7, at 187 (arguing that genetic populations or human "demes" have no moral standing).

${ }^{11}$ See, e.g., id. at 184 (accepting the idea of group control "would significantly complicate the work of population genomicists"); Sharp and Foster, supra note 8, at 49 (describing the costs and demands on researchers when formal community approval is required). 
group rights implicates larger debates and demands of indigenous peoples for rights to governance, territorial integrity, cultural autonomy, and other incidents of self-determination. ${ }^{12}$

In this essay, I wish to focus on an underlying theoretical issue which I believe seriously affects our collective response to the idea of group rights in the genetic-control context. That issue is this. To what extent are our responses to claims of group rights hampered by our bringing to the table (consciously or unconsciously) a model which is structured to acknowledge only individual concerns? Put another way, to what extent are our objections to group rights in this context a product of our inability (or refusal) to imagine the idea of group rights, rather than the product of truly substantive concerns?

This underlying issue of conceptualization is manifest in the responses of many commentators to the idea of group genetic-control rights. Consider, for instance, the following observation by Eric Juengst, a leading commentator in the field. "[Some] argue," he writes, "that groups, once targeted for ... study, should be given the opportunity to decline participation on behalf of their members by being asked in advance for permission to contact and recruit individuals from their membership ... ." "These proposals have vast practical and ethical implications. If groups have interests that require protections like those of individual subjects, a layer of research arrangements would be necessary that our individually-oriented biomedical research ethic is ill-prepared to define or delimit."13

Juengst may well be right that there are significant psychological barriers to the idea of

\footnotetext{
${ }^{12}$ See Barker, supra note 1, at 580 (such scientific projects involve confrontation "of indigenous rights to sovereignty and self-determination within the legal and scientific realms of law, policy, and protocol”).

${ }^{13}$ Juengst, supra note 7 , at 184 (footnotes omitted).
} 
group genetic-control rights. However, in this essay I shall argue that the notion that group control of genetic testing and use is incompatible with contemporary notions of legal rights is greatly exaggerated. Group control is, in fact, a natural implementation of many existing legal theories and is viewed in many contexts as an enforceable legal right. Although there may be valid objections to particular instances of group control of genetic testing and use, there is no generally valid objection, as a matter of theory, to the implementation of this right. Wholesale objections are, thus, more a product of unexamined bias than considered reasons for the rejection of this right.

\section{Groups as Rights-Holders: General Arguments}

Contemporary Western jurisprudence is replete with broad, philosophical statements that identify individual rights as the appropriate foundation for protection of human rights and liberties. Rooted in natural rights theories, social compact theories, Kantian notions of the individual, and other philosophical antecedents, it is generally assumed by liberal democratic governments that legally cognizable human rights are individual rights, which stand against the potential tyranny of government. ${ }^{14}$ Group rights, collective rights, or societal rights are simply

\footnotetext{
${ }^{14}$ See, e.g., A. Buchanan, “Assessing the Communitarian Critique of Liberalism,” Ethics 99 (1989): 852-882, at 854; G. Walker, “The Idea of Nonliberal Constitutionalism,” in I. Shapiro and W. Kymlicka eds., Ethnicity and Group Rights: Nomos XXXIX (New York: New York University Press, 1997): 154-184, at 154-156. The claim that these theories in fact yield the individualistic conclusions commonly assumed is contested by others. See, e.g., N. MacCormick, Legal Rights and Social Democracy: Essays in Legal and Political Philosophy (Oxford: Clarendon Press, 1982), at 261 ("The Kantian ideal of respect for persons implies ... an obligation in each of us to respect that which in others constitutes any part of their sense of their own identify.” For many people, identity includes participation in "cultural communit[ies,] ...
} 
ignored in the American Constitution, the United Nations Charter, and other watershed documents as a protected source or expression of human rights as either a philosophical or operative matter. ${ }^{15}$

In the day-to-day workings of American jurisprudence, expressed fidelity to this principle is strong. Individual rights are assumed, for both positive and negative reasons, ${ }^{16}$ to be the building blocks for legal rights and legal responsibilities. Legal interests, whether asserted in tort, contract, constitutional law, or otherwise, are immediately and reflexively envisioned in individual terms. Whether we are speaking of private wrongs or wrongs by government, it is generally assumed in American jurisprudence that it is the individual who is the focus of concern. ${ }^{17}$ Group rights, which are experienced and exercised with others, are generally ignored requir[ing] [their] protection and expression in appropriate institutional forms.”).

${ }^{15}$ The absence of different conceptions of rights in Western jurisprudence is, of course, not always simply the result of philosophical oversight; often, those with power and influence have been keenly aware of the claims of groups and have deliberately eclipsed their interests. For instance, the omission of group rights in early United Nations documents was the product of a belief that political troublesome minorities in member states should not be given legal status and recognition. See O. Goldman, "The Need for an Independent International Mechanism to Protect Group Rights: A Case Study of the Kurds," Tulsa Journal of Comparative and International Law 2 (1994): 45-89, at 51-53; J. Robinson, "International Protection of Minorities: A Global View,” Israeli Year Book on Human Rights 1 (1971): 61-91, at 77.

${ }^{16}$ See, e.g., G. Doppelt, "Illiberal Cultures and Group Rights: A Critique of Multiculturalism in Kymlicka, Taylor, and Nussbaum,” Journal of Contemporary Legal Issues 12 (2002): 661-692 (arguing that legal recognition of cultural, ethnic, national, religious or other group rights is socially and politically divisive, and violates democratic egalitarian guarantees).

${ }^{17}$ In a typical statement of this view, a prominent scholar argued:

[C]ivil rights - fundamentally the rights of citizenship, of a member of the polity ... inhere in individuals, not in groups. ... That is a fundamental principle of democracy. It is explicit in the Declaration of Independence, the Constitution (perhaps especially in the Bill of Rights) and in the major civil rights legislation over the decades. 
as a jurisprudential category. ${ }^{18}$

Upon deeper reflection, of course, this assumed anti-group bias in Western jurisprudence is fraught with theoretical and practical weaknesses. For instance, whether groups (“collectivities”) can possess moral rights has been the subject of extensive scholarly commentary. If one begins with the proposition that all moral value is rooted in the well-being of individual human beings, then the idea that moral rights "can inhere in collectivities as such" is obviously untenable. ${ }^{19}$ If - on the other hand - one accepts the moral value of distinctly collective interests, the idea of morally grounded group rights follows. ${ }^{20}$ Group rights, in this view, are intended to protect distinctly collective interests, such as larger societal recognition and

A Bill to Amend the Civil Rights Act of 1957 to Extend the Life of the Commission on Civil Rights, and for Other Purposes, 1983: Hearings on S. 1189 before the Subcomm. on the Constitution of the Sen. Comm. on the Judiciary, 98 ${ }^{\text {th }}$ Cong., $1^{\text {st }}$ Sess. 20 (1983) (statement of Chester E. Finn, Jr., Professor of Education and Public Policy, Vanderbilt University).

${ }^{18}$ See, e.g., Aviam Soifer, Law and the Company We Keep (Cambridge, Mass.: Harvard University Press, 1995).

${ }^{19}$ See M. Hartney, “Some Confusions Concerning Collective Rights,” Canadian Journal of Law and Jurisprudence 4 (1991): 293-314, at 312. See also Buchanan, supra note 14.

${ }^{20}$ As Michael McDonald writes:

What the liberal takes as basic and unquestionable is the idea that the individual is the measure of everything; hence, the liberal believes that correct normative principles treat the individual as the fundamental unit of value ... . Individuals are regarded as valuable because they are choosers and have interests. But so also do communities make choices and have values. Why not then treat communities as fundamental units of value ...?

M. McDonald, "Should Communities Have Rights? Reflections on Liberal Individualism," Canadian Journal of Law and Jurisprudence 4 (1991): 217-237, at 237. See also D. Réaume, “Individuals, Groups, and Rights to Public Goods,” University of Toronto Law Journal 38 (1988): 1- ， at 13-17, 24; R. Garet, “Communality and Existence: The Rights of Groups,” Southern California Law Review 56 (1983): 1001-1075. 
respect for the group’s decision-making mechanisms, rights, and powers. ${ }^{21}$

From the point of view of what rights $d o$, there is no structural reason why legal rights which guarantee particular states of affairs, in law - cannot be afforded to groups as well as to individuals. ${ }^{22}$ Indeed, the idea that Western jurisprudence abjures [shuns] group rights is, itself, an obvious conceptual fallacy. In international law, governments - which recognize and enforce individual rights - are themselves groups with recognized legal status. In addition, groups of all kinds are recognized in a myriad of circumstances. Binding international agreements and nonbinding international declarations recognize group rights in the contexts of cultural property, ${ }^{23}$

${ }^{21}$ See McDonald, supra note 20, at 218, 220.

${ }^{22}$ See, e.g., V. Amar and A. Brownstein, “The Hybrid Nature of Political Rights,” Stanford Law Review 50 (1998): 915-1014; L. Rodriguez-Abascal, "On the Admissibility of Group Rights,” American Survey of International and Comparative Law 9 (2003): 101-110, at 102.

${ }^{23}$ See, e.g., Convention on the Means of Prohibiting and Preventing the Illicit Import, Export, and Transfer of Ownership of Cultural Property, Nov. 14, 1970, 823 U.N.T.S. 231 (recognizing cultural property rights of nations and other groups). 
education, ${ }^{24}$ religion, ${ }^{25}$ and genocide. ${ }^{26}$ National, ethnic, religious, and linguistic minorities, ${ }^{27}$ as well as indigenous peoples, ${ }^{28}$ are afforded group rights. ${ }^{29}$

${ }^{24}$ See, e.g., Convention Against Discrimination in Education, art. 5, Dec. 14, 1960, 429 U.N.T.S. 93 (recognizing minority population control of educational activities, including the maintenance of schools and the use in education of their own language).

${ }^{25}$ See, e.g., Declaration on the Elimination of All Forms of Intolerance and of Discrimination Based on Religion or Belief, art. 1, U.N. GOAR, 36 ${ }^{\text {th }}$ Sess., Supp. No. 51, U.N. Doc. A/36/684 (1981) (freedom of religion shall include individual practice and practice in community with others).

${ }^{26}$ See Convention on the Prevention and Punishment of the Crime of Genocide, Dec. 9, 1948, 78 U.N.T.S. 277; D. Alonzo-Maizlish, “In Whole or in Part: Group Rights, the Intent Element of Genocide, and the 'Quantitative Criterion,'” New York University Law Review 77 (2002): 1369-1403, at 1375-1382.

${ }^{27}$ See, e.g., Declaration of the Rights of Persons Belonging to National or Ethnic, Religious and Linguistic Minorities, art. 3, Dec. 18, 1992, G.A. Res. 135, U.N. GAOR, U.N. Doc. A/RES/47/135 (1993); International Convention on the Elimination of All Forms of Racial Discrimination, Mar. 7, 1966, 660 U.N.T.S. 195 (authorizing measures necessary to secure adequate advancement of certain racial and ethnic groups).

${ }^{28}$ See, e.g., Convention (No. 169) concerning Indigenous and Tribal Peoples in Independent Counties, International Labour Conference, June 27, 1989, available at <http://www.unhchr.ch/html/menu3/b/62.htm> (last visited May 19, 2006) (recognizing the rights of indigenous populations and the need to preserve their institutions, persons, property, and labor); U.N. Econ. \& Soc. Council [ECOSOC], Sub. Comm. on Prevention of Discrimination \& Prot. of Minorities, Draft United Nations Declaration on the Rights of Indigenous Peoples, art. 29, in Report, U.N. Doc. E/CN.4/Sub.2/1994/56/Annex to Res. 45 (Oct. 28,1994 ) (indigenous peoples "have the right to special measures to control, develop, and protect their sciences, technologies and cultural manifestations, including human and other genetic resources ...”). As one scholar has observed, "international law is developing with particular attention to indigenous peoples in a way that is favorable to their demands." S. Anaya, "Superpower Attitudes Toward Indigenous Peoples and Group Rights,” American Society of International Law Proceedings 93 (1999): 251-260, at 251. See also S. Wiessner, "Rights and Status of Indigenous Peoples: A Global Comparative and International Legal Analysis,” Harvard Human Rights Journal 12 (1999): 57-128.

${ }^{29}$ For a general discussion of guarantees of group rights under international and foreign domestic laws, see R. Clinton, "The Rights of Indigenous Peoples as Collective Group Rights," Arizona Law Review 32 (1990): 739-747, at 743-746; Goldman, supra note 15, at 52-65; N. Lerner, Group Rights and Discrimination in International Law (The Hague, Netherlands: 
Within the United States, we routinely recognize the distinct interests and decisionmaking power of groups in law. Lesser political and governmental entities, such as states, counties, and municipal governments, enjoy unquestioned legal status. Since the time of the country's founding, the Supreme Court and Congress have recognized Indian tribes as quasisovereign nations. ${ }^{30}$ Other non-governmental groups that have enjoyed legal or de facto recognition of their interests and powers include for-profit and charitable corporations, unincorporated associations, partnerships, families, labor unions, racial minorities, ${ }^{31}$ and religious groups. ${ }^{32}$ Commitments to freedom of association, freedom of contract, the institution of marriage, and other Western legal commitments involve -- explicitly or implicitly -- the recognition of legally binding, group-based rights. ${ }^{33}$

It is true that the group rights asserted in these examples are quite varied in nature. In some cases, groups exercise decisionmaking powers as groups, using their own designated processes (for example, corporations, local governments, religious groups, and Indian tribes). In

Kluwer Law International, 2003).

${ }^{30}$ The rights of Indian tribes in the United States are grounded in historical documents that recognize rights of group autonomy, not individual freedoms. See Clinton, supra note 29, at 745.

${ }^{31}$ Affirmative action and other race-conscious remedies can be seen as efforts to address group-based interests that transcend individual injuries and the limitations of individual claims. See, e.g., O. Fiss, “Groups and the Equal Protection Clause," Journal of Philosophy and Public Affairs 5 (1976): 107-177, at 171-172.

${ }^{32}$ See, e.g., F. Gedicks, “Toward a Constitutional Jurisprudence of Religious Group Rights,” Wisconsin Law Review (1989): 99-169, at 129-137 (discussing judicial and legislative sensitivity to the prerogatives and needs of religious groups).

${ }^{33}$ See T. Pogge, "Group Rights and Ethnicity," in Ethnicity and Group Rights: Nomos XXXIX, supra note 14: 187-221, at 196-197. 
other cases, “group” status confers far less (for instance, the simple acknowledgment of perceived group needs in affirmative action efforts and laws protecting cultural property). ${ }^{34}$ The form of group recognition may have important consequences for the idea of group rights in any particular context, as discussed below. At this point, it is important to appreciate only that recognition of group interests, whether based upon territory, culture, ethnicity, or other grounds, is a routine legal matter; and that the denial of rights based upon these interests requires more than the simple assertion that group rights are alien to our law. As Thomas Pogge has stated, "the question therefore cannot be whether we should depart from our ordinary practice of recognizing only ...rights of individuals ... . There is no such ordinary practice. Group rights ... are staples of standard Western liberal thought.”35

The question remains whether group rights should be recognized in the context of genetic information control. It is to that question that we now turn.

\section{Groups as Rights-Holders: Genetic Testing and Use}

There are many reasons why identifiable groups whose members are the "source” for genetic testing programs may wish to assert demands for control. Groups may wish to ensure that they (or their members) reap the health benefits or commercial earnings that their genetic information yields. They may wish to oppose the idea of genetic testing or commercial

\footnotetext{
${ }^{34}$ Cf. id. at 191-193 (discussing “group rights proper”, “group-specific rights”, and “group-statistical rights”).

${ }^{35} I d$. at 197.
} 
exploitation of that testing, on cultural or ethical grounds. They may wish to avoid collective risks that these projects present to members of a genetically identifiable group. If particular diseases or disabilities are associated with particular genetic variations, and those variations are (in turn) associated with particular groups, there is a real risk of group discrimination and stigmatization. ${ }^{36}$

Whatever the reasons for its assertion, the idea of group control or "veto power" over genetic testing and its uses has been vigorously opposed on various grounds. Some of the reasons for opposition, such as resource questions, are general restraints on any research project design. Other reasons for opposition challenge the essential premise of group rights and group control. It is the validity of the latter that we will examine here.

(a) What is a "group"?

(1) Structural challenges

As an abstract matter, the idea of a socially or legally cognizable "group" is very broad and generally refers to persons who share certain common characteristics or interests. ${ }^{37}$ These characteristics or interests may be chosen by the individuals involved (e.g., geographical residence, cultural adoption, self-identified racial or religious membership) or they may be

${ }^{36}$ See Sharp and Foster, supra note 8, at 41; A. Caplan, "Handle With Care: Race, Class, and Genetics,” in T. Murphy and M. Luppé eds., Justice and the Human Genome Project (Berkeley: University of Berkeley Press, 1994): 30-45, at 30-33.

${ }^{37}$ See, e.g., Lerner, supra note 29 , at 36. 
involuntarily conferred (e.g., country of birth, biological race, or tribal, religious, or other membership by parentage).

The fluidity and complexities of group definition has made it an essentially contested concept. ${ }^{38}$ Theorists have advanced varying formulae for group recognition in particular contexts. For instance, Thomas Pogge argues that an "ethnic group” must meet three conditions: the members of the set must understand themselves as descendants of members of a historical society (in a broad sense, including tribes, principalities, and others); they must share a common culture, or partial culture, which they take to be connected, through a continuous history; and the group must contain all, or nearly all, of the persons who, within the relevant state, are taken to share the group’s descent and culture. ${ }^{39}$ Natan Lerner, in an analysis of group recognition in international law, stresses the purposes and goals of asserted groups, ${ }^{40}$ the relationship of the group to other groups, ${ }^{41}$ the permanence of the group, ${ }^{42}$ the naturalness or spontaneity of the

${ }^{38}$ Indeed, as one scholar has noted, even "indigenous peoples" and "indigenous populations" - which are widely used in international law - are contested terms. Anaya, supra note 28 , at 251.

${ }^{39}$ Pogge, supra note 33, at 193-194. Other theorists stressing similar factors in group recognition include A. Addis, "Individualism, Communitarianism, and the Rights of Ethnic Minorities,” Notre Dame Law Review 67 (1992): 615-676, at 656 (citing shared history and culture); Statement of UNESCO Meeting of Experts on Further Study of the Rights of Peoples (Paris, Feb. 1990), quoted in Goldman, supra note 15, at 48 (citing common historical tradition, racial or ethnic identity, cultural homogeneity, linguistic unity, religious or ideological affinity, territorial connection, and/or common economic life).

\footnotetext{
${ }^{40}$ See Lerner, supra note 29, at 36.

${ }^{41}$ See, e.g., id. at 36, 39.

${ }^{42}$ See id. at 36-38.
} 
group, ${ }^{43}$ and whether group membership is voluntary or involuntary in nature. ${ }^{44}$ Still other theorists emphasize shared normative understandings, ${ }^{45}$ the importance of the group to personal identity, ${ }^{46}$ and whether the well-being of group members is at least in part determined by group well-being. ${ }^{47}$

All of these criteria involve acknowledged vagueness; for instance, most definitions require only that the group in question have some (unspecified) number of these characteristics to qualify for recognized "group" status. ${ }^{48}$ In addition, there is no specification, in these lists, as to how broad or narrow the required commonalities must be, or - in the case of shared history or culture - how long these commonalities must exist in time. ${ }^{49}$ As Pogge puts it, "[h]ow important is it for qualifying as a Navajo, for example, what fraction of one's ancestry is Navajo, whether one checks off the 'Native American' category on affirmative action questionnaires, how much one knows about Navajo history, culture, and affairs, [or] how one is regarded by other Navajos

${ }^{43}$ See id.

${ }^{44}$ See id. Lerner argues that under international law, recognized groups involve factors that are beyond the control of members; voluntary associations are not recognized. See id. at 3639.

${ }^{45}$ See McDonald, supra note 20, at 218.

${ }^{46}$ See id. at 219; Fiss, supra note 31, at 148. See also Statement of UNESCO Meeting, supra note 39, quoted in Goldman, supra note 15, at 48 (“'The group as a whole must have the will to be identified as a people or the consciousness of being a people - allowing that groups or some members of such group[s], though sharing [other required] ... characteristics, may not have the will or consciousness."”).

${ }^{47}$ See Fiss, supra note 31, at 148.

${ }^{48}$ See, e.g., Statement of UNESCO Meeting, supra note 39, quoted in Goldman, supra note 15 , at 48 .

${ }^{49}$ See Pogge, supra note 33, at 194-195. 
...?”50 Groups, whether identified by any cluster of the assembled characteristics, often lack "clear identity" or the presence of reasonably clear boundaries for determining membership, responsibilities, benefits, and authoritative voice in the group's affairs. ${ }^{51}$

In addition, for groups to be recognized social, political, or legal actors, they must have "effective agency," or the ability "to form goals, deliberate, choose, intend, act, and carry out

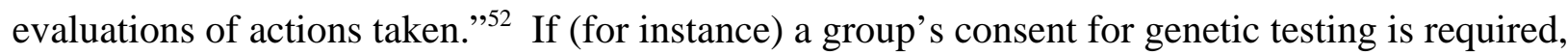
there must be some kind of effective mechanism for ascertaining the group's stand on the matter and some effective leadership or other structure with whom those seeking permission for the project can deal.

Finally, there is the problem of "nesting," on both an individual and group level. On the individual level, general criteria for "group” status - even if established with great specificity may result in multiple and possibly conflicting group memberships for individuals. For instance, a single individual may (by birth) be a member of particular geographical, religious, and racial groups, and may (by choice) be a member of groups based upon residence, self-identified ethnicity, chosen religious identity, and other factors. On the group level, “nesting” will occur when smaller groups are (by definition) part of larger, more inclusive groups. For instance, as Richard Sharp and Morris Foster describe, an individual Mohawk community, if located on a reservation with other Mohawk communities, may be part of a larger, politically defined

\footnotetext{
${ }^{50} I d$. at 195.
}

${ }^{51}$ See J. Nickel, “Group Agency and Group Rights," in Ethnicity and Group Rights: Nomos XXXIX , supra note 14: 235-256, at 235.

${ }^{52} I d$. See also Statement of UNESCO Meeting, supra note 39, quoted in Goldman, supra note 15, at 48 ("Possibly, the group must have institutions or other means of expressing its common characteristics and will for identity.”). 
community. That larger reservation-based community may consider itself part of a common Mohawk national community. And the Mohawk nation is, itself, a part of the League of Iroquois and may be represented, as a political matter, by the National Congress of American Indians. ${ }^{53}$ On either level, the nesting problem means that individuals and groups may be subject to conflicting identities and conflicting interests.

The critical question for our inquiry is whether any of these structural issues involving group identity and function are fatal to the recognition of group genetic-control claims. That the criteria for group recognition may be uncertain or arbitrary, that questions of agency may exist, and that individuals and groups may be subject to conflicting group loyalties, will complicate the idea of group rights to control genetic testing and use of genetic information is beyond question. However, are these problems fatal to the implementation of this goal?

There may be certain proposed "groups" - for instance, all Irish Americans, or the world's Ashkenazi Jewish women - whose numbers are so large, and whose sense of group cohesion and group decisionmaking are so weak, that the idea of group rights in the genetic control context is completely unworkable. By and large, however, it is not these groups who are making genetic-control claims. Rather, it is groups who generally meet some or all of the recognition criteria set forth above, and who have - by virtue of their assertion of the claim some kind of authoritative voice or structure with whom to deal. The question is, what of these groups?

In considering this question, we must return to the observations about group status in international and domestic law with which we began. Despite the rhetorical primacy of the

\footnotetext{
${ }^{53}$ See Sharp and Foster, supra note 8, at 47.
} 
individual in Western jurisprudence, group interests, relations, and decision-making structures are recognized throughout international and domestic law. Local, state, and national political entities, religious groups, cultural groups, corporate groups, minority groups, indigenous and tribal groups, and a myriad of others have distinctly recognized and protected interests in law despite the definitional uncertainties, agency issues, and nesting problems that surround them. ${ }^{54}$ We simply accept such problems as part of the analytical terrain; we accept, for instance, that sorting out the conflicting (group) interests surrounding "cultural property" is as manageable as sorting out the conflicting (individual and group) interests surrounding "due process of law." Structural issues of these kinds are not unique to group genetic-control claims; they are involved in the recognition of all group entities and interests by law. Indeed, in a broader sense, problems of definitional uncertainties, agency issues, and overlapping or conflicting authority are not limited to legal treatment of groups; they are an endemic part of any attempt to organize any human activity in terms of legal rights and powers.

Attempting to honor group claims in the field of genetic research would be undoubtedly more cumbersome, time-consuming, and perhaps preclusive (of our ends), should groups refuse particular research proposals, collection methodologies, patents, or uses. However, these are

${ }^{54}$ For instance, "there is no uniformly accepted definition [in international law] for a 'minority' [group], despite the dominance of its use.” Goldman, supra note 15, at 47 (footnote omitted). The most widely accepted definition identifies a minority group as "[a] group numerically inferior to the rest of the population of a State, in a non-dominant position, whose members ... possess [distinctive] ethnic, religious or linguistic characteristics ..., and show, if only implicitly, a sense of solidarity, directed towards preserving their culture, traditions, religion, or language." F. Capotorti, "Study on the Rights of Persons Belonging to Ethnic, Religious and Linguistic Minorities”, U.N. Doc. E/CN.4/Sub. 2/384/Rev.1, U.N. Sales No. E.78.XIV.1 (New York: United Nations, 1979), at 96. This obviously leaves many questions unanswered. 
costs imposed by group control, not structural or analytical impossibilities. Just as we tolerate and accommodate the societal costs involved in honoring group claims (and other claims) in other contexts, we can - if we wish - tolerate and accommodate the societal costs involved in this context as well.

\section{(2) Substantive challenges}

Critics have also raised substantive challenges to the ability of particular groups to assert genetic-control claims. In particular, critics challenge the moral capacity or qualifications of groups to control the genetic decision-making of their members.

In the genetic-control context, “groups” can be identified in two different ways. First, one might genetic populations, or "demes”, which are comprised of individuals who share relevant genetic information. In addition, there are as self-identified or other-identified social groups or "ethnoi”, whose members are the subject of genetics testing and use.

Objections to group control by demes, or genetic populations, are well summarized by Eric Juengst. If, he writes, by “groups” “we mean genetic populations, or human 'demes', we are not talking about the kind of human groups that can be approached for permission: they have no moral standing, deserve none, and in any case are unidentifiable until the research has been conducted." 55

To examine this argument, let us begin with the question of group pre-research control. If a particular genetic population cannot be identified (as a scientific or social matter) before the

\footnotetext{
${ }^{55}$ Juengst, supra note 7 , at 187.
} 
research is conducted, then denial of pre-research control to such groups is obviously justified.

A group that cannot be identified, by its "members" or by others, cannot assert a common interest of any of the kinds that we have identified in this context. The group qua group will have no group cultural, ethical or other grounds on which to oppose the project, or group interests in the project's benefits or profits.

Let us consider, however, a different case: one where the genetic population in question is certain, or very likely, identifiable before the research is done. In a recent article, Graeme Laurie discusses the interests of family members in shared familial genetic information. ${ }^{56} \mathrm{He}$ observes that traditionally, when we have asked where the control of information should lie, the answer has been "the source." ${ }^{57}$ However, "[i]n the genetic sphere, ... such an answer is simplistic and unsatisfactory." ${ }^{58}$ He writes:

[G]enetic information differs from other forms of medical information because it pertains to a range of people and not solely to one individual. In this respect, it gives rise to special problems concerning how the information should be gathered, stored, accessed, and used. ... [O]ne cannot ignore the fact that genetic information derived from the sample also reveals information about the relatives of the sample source. These persons can base a claim to the information on precisely the same grounds as the source, namely: "I have a claim because it is about me."

${ }^{56}$ G. Laurie, “Challenging Medical-Legal Norms: The Role of Autonomy, Confidentiality, and Privacy in Protecting Individual and Familial Group Rights in Genetic Information,” Journal of Legal Medicine 22 (2001): 1-54.

${ }^{57} I d$. at 3 .

${ }^{58} I d$.

${ }^{59} I d$. Diseases for which genetic predispositions have already been identified include cystic fibrosis, adult onset polycystic kidney disease, Huntington's chorea, Alzheimer's disease, breast cancer, muscular dystrophy, sickle-cell anemia, and others. See D. Peters, "Risk Classification, Genetic Testing, and Health Care: A Conflict Between Libertarian and Egalitarian Values?”, in T. Peters ed., Genetics: Issues of Social Justice (Cleveland: The Pilgrim Press, 
Indeed, "genetic test results can offer a high degree of specificity, both in terms of predicting the likelihood of disease in other family members and in terms of putting flesh on the bones of a suspicion that has heretofore been unconfirmed." ${ }^{\prime 60}$ Specific information can confer "a degree of 'certainty’ about future ill health or even the mode and manner of one’s own death.”61 This information may alter one’s self-perception and create anxiety, depression, and a sense of stigmatization among all of those who believe themselves to be so identified. ${ }^{62}$ Family members may also be the victims of discrimination by third parties, who act on the prejudices and predictions that this information may arouse. ${ }^{63}$

The example of family consanguinity illustrates that it is possible for pre-testing, probable-genetic-similarity alone to identify a group with legitimate and legally cognizable genetic-control interests. ${ }^{64}$ The frequency of such groups beyond the family context is a matter

1998): 205-217, at 205; T. Peters, “Genes, Theology, and Social Ethics: Are We Playing God?”, in id.: $1-45$, at 3.

${ }^{60}$ Laurie, supra note 56 , at 3.

${ }^{61} I d$. at 3-4.

${ }^{62} I d$. at 11-13. See also D. Kevles, In the Name of Eugenics: Genetics and the Uses of Human Heredity (New York: Alfred A. Knopf, 1985), at 297-298 (citing studies).

${ }^{63}$ See T. Peters, supra note 59, at 4 (footnotes omitted) (“Among Fortune's 500 top companies, twelve already report using genetic testing for employment purposes. ... Underwriters already deny or limit coverage to gene-related conditions such as sickle-cell anemia, artherosclerosis, Huntington's disease, Down syndrome, and muscular dystrophy. ... Individuals with genetic predispositions to expensive diseases may become unemployable, uninsured, and finally unable to acquire medical care.”). See also P. Billings et. al., "Discrimination as a Consequence of Genetic Testing," American Journal of Human Genetics 50 (1992): 476-482, at 476 (genetic discrimination and stigmatization "exists and is manifested in many social institutions, especially in the health and life insurance industries").

${ }^{64} \mathrm{Cf}$. Genetic Privacy Act (GPA), §3 (m), available at $<$ http://www.ornl.gov/sci/techresources/Human_Genome/resource/privacy/privacy2.html > (last 
of question. Evidence to date indicates that almost all human social groups exhibit wide genetic variation; only human populations that have been physically isolated for a substantial period show an increase in general genetic homogeneity. The infrequency of genetically identified groups does not mean, however, that we should dismiss this as a possible category for group rights. Where a genetically-identified group is present, and is the subject of genetic study, we should not be free to ignore its interests.

Let us assume, then, that the problem of identifiability has been met, either because the genetic group is identifiable (with reasonable certainty) before the research commences, or because the research itself has identified the genetic group, and the question is post-research control. The objections that Juengst summarizes do not end at this point. Rather, they argue that the idea of "rights” for human demes is still nonsensical, because such groups "have no moral standing, deserve none”, and, in any event, have no capacity to exercise the rights that they might seek. ${ }^{65}$

These arguments are curious. Why would a group, whose members are bound by genetic similarity, necessarily fail (and deserve to fail) the test of moral or practical standing? One can imagine how a group whose members are linked by the presence of a single, identified gene - for instance, the presence of BRCA 1 in Ashkenazi Jewish women ${ }^{66}$ - might be too large, and the

visited May 21, 2006) (“private genetic information” subject to the Act's proposed safeguards includes "any information about an identifiable individual that is derived from the presence, absence, alteration, or mutation of a gene or genes, or the presence or absence of a specific DNA marker or markers, and which has been obtained: (1) from an analysis of the individual's DNA; or (2) from an analysis of the DNA of a person to whom the individual is related”).

${ }^{65}$ See Juengst, supra note 7, at 187.

${ }^{66}$ See J. Struewing et. al., "The Risk of Cancer Associated with Specific Mutations of BRCA 1 and BRCA 2 Among Ashkenazi Jews,” The New England Journal of Medicine 336 
shared comonality too small, to forge any true group interest or identity. However, this failure occurs not because this is a genetic group, per sé, but because it fails to meet the criteria for "groupness," in the sense of common interests or other criteria that we have (on some other basis) previously established. ${ }^{67}$ There is no a priori reason why genetic groups should be deemed, in every case, to fail to meet whatever structural requirements we set for group recognition in this context. Indeed, it is perfectly imaginable that a group, whose members are bound by genetic ties, would have strong common interests and practical goals - not the least of which is the avoidance of group discrimination and stigmatization.

Let us move now to groups of the second kind: self-identified or other-identified social groups or “ethnoi,” whose group identities are rooted in culture, language, race, territorial occupation, or other characteristics. ${ }^{68}$ It is these groups (for instance, indigenous peoples, and geographically or culturally isolated peoples) who are the most common subjects of genetic research, and who have been the most forceful in asserting genetic-control claims. ${ }^{69}$

The most obvious objection to the demands of these groups is that they are unacceptable "surrogates for demes": ${ }^{70}$ that is, that their members lack sufficient genetic similarity to give them standing to assert genetic-control claims. For instance, if the dangers from the project lie

(1997): 1401-1408.

${ }^{67}$ See text at notes 37-54, supra.

${ }^{68}$ See Juengst, supra note 7 , at 187.

${ }^{69}$ See, e.g., Barker, supra note 1, at 587-597; J. Christie, "Whose Property, Whose Rights?”, Cultural Survival Quarterly 20 (1996): 34-41; L. Whitt, “Cultural Imperialism and the Marketing of Native America,” American Indian Culture and Research Journal 19 (1995): 1-31, at 17-19.

\footnotetext{
${ }^{70}$ See Juengst, supra note 7, at 189.
} 
in the potential stigmatization or discriminatory treatment of persons who are found to carry a particular genetic variation, these dangers (and the moral rights they create) apply only to those who share or very likely share the characteristics in question. If the members of a particular cultural, historical, racial, or other group in fact lack genetic similarity, there is (under this argument) no reason to afford genetic-control rights to this group.

The answer to this argument inheres in the question that it poses. If we are, in fact, looking for "surrogates for demes" - in a demonstrable, verified, scientific sense - then no social group will surely achieve this status. Groups whose membership and authority are based upon culture, history, ethnicity, territorial proximity, or other factors will at best have possible genetic similarities - nothing that makes them, with any assurance, "surrogates for demes.”

The "demic certainty" that this objection requires is not, however, what genetic research of this kind has assumed. For instance, as Juengst has observed, "it is the history, migration, and relative disease burdens of humanity’s many socially defined groups, not our anonymous demes, that derives most descriptions and defenses of population-genomics research.”71 Indeed, it seems

${ }^{71}$ See id. at 190. As Joanne Barker describes the original design of the Human Genome Diversity Project:

Because of the similarities [among members of] ... populations, [it was assumed that] the HGDP would only need to collect samples from about 10 percent of the world's total groups, meaning anywhere between 500-700 of the estimated 5,000-7,000. The selection of these groups would be determined by their biological and geotraphical isolation ("isolates of historic interest") and linguistic integrity. Because of the genetic similarities within groups, only about 25 individuals from each would need to be sampled.

Barker, supra note 1, at 574-575. See also L Cavalli-Sforza et. al., supra note 4, at 490 (target popoulations are those who "have been isolated for some time, are likely to be linguistically and culturally distinct, and are often surrounded by geographic boundaries”). 
quite inexplicable to the members of these groups why - if their group status makes them targets for genetic research - that group status is, in turn, insufficient to allow their assertion of geneticcontrol claims. For instance, if "group status” confers sufficient commonality for targeted genetic research, then presumably it also confers sufficient commonality for the risk of stigmatization or discrimination. ${ }^{72}$

The demand for "demic certainty" is also flawed, in that it narrows too profoundly the range of interests that groups, in this context, can legitimately assert. If we require "demic certainty," we implicitly assume that it is genetic similarity alone that generates cognizable group interests. In fact, the claims of groups, particularly indigenous, tribal, and territorially isolated groups, go far beyond those interests. These groups claim a violation of culture. They claim a disregard of ethics, ${ }^{73}$ and commercial exploitation. ${ }^{74}$ They claim a loss of autonomy, territorial integrity, and governmental respect. ${ }^{75}$ As explained by Aroha Te Pareake Mead:

[For the Maori and others,] genes and combinations of genes are not the

${ }^{72}$ See, e.g., Barker, supra note 1, at 597-598 (discussing fears, articulated by the National Research Council, that DNA samples might be used against donors and their communities - for instance, for denial of health insurance to members of groups found to be "genetically predisposed" to disease). "Distinctive populations" in which potentially stigmatizing diseases have already been found include the Old Order Amish (mental illness) and the Pima tribe in Arizona (diabetes). For discussions of these findings, see Greely, supra note 7, at 54-55.

${ }^{73}$ See, e.g., Barker, supra note 1, at 585, 591-92, 595; Christie, supra note 69, at 35-36; Mead, supra note 6, at 48.

${ }^{74}$ See, e.g., Barker, supra note 1, at 594; R. Grounds, “The Yuchi Community and the Human Genome Diversity Project: Historic and Contemporary Ironies,” Cultural Survival Quarterly 20 (1996): 64- , at 64.

${ }^{75}$ See Barker, supra note 1, at 578, 580 (“[Indigenous] [p]eoples demand historicity, politicality and the recognition of their legal stakes in being articulated as such.” Their claim "is to the entrenchment of indigenous rights to sovereignty and self-determination within the legal and scientific realms of law, policy, and protocol ....”). 
sole property of individuals. They are part of the heritage of families, communities, clans, tribes, and entire indigenous nations. ...

[As a result,] [t] he HGDP is viewed by many indigenous peoples as offensive, frivolous, and disrespectful of the integrity of nature, life, the ancestors - all that is sacred. ...

As outsiders, who will the HGDP approach? Who will they consider to have the definitive vote? ... Can consent be reduced to an individual level when the very nature of genetic research implicates a wider group? ${ }^{76}$

Just as cultural, ethical, and governmental concerns are deemed by the majority culture to be valid and vital interests that justify the power of local and national governments, so those concerns must be recognized as valid and vital interests of other "social” groups who are the targets of genetic research and who respond with the assertion of assert genetic-control claims. The sufficiency of group interests in any setting to establish group rights is, of course, a deep and complicated inquiry. However, we cannot - on the grounds of "moral capacity" or "standing” simply choose to disregard, as a class, the rights of social groups or "ethnoi" to assert geneticcontrol claims.

Finally, the ability of social or cultural groups to control the genetic decision-making of their members is implicitly challenged by what might be called the "critique of cultural orthodoxy". ${ }^{77}$ Scholars have observed that culture is "a process, or dialogue, through which individuals continually renegotiate the world and their place in it."78 Cultural identity is continually evolving, as a result of both internal dissent and outside challenges. Madhavi Sunder

${ }^{76}$ Mead, supra note 6, at 48, 49-50.

${ }^{77}$ See, e.g., M. Sunder, “Intellectual Property and Identity Politics: Playing with Fire," Journal of Gender, Race and Justice 4 (2000): 69- 98, at 76.

${ }^{78}$ M. Sunder, “Cultural Dissent,” Stanford Law Review 54 (2001): 495-567, at 522-523. 
argues that the role of cultural dissent is both powerful and unavoidable; it "enhances individual autonomy and equality within culture, enables cultural 'outsiders' to challenge discrimination without fear of losing their culture, challenges cultural relativist arguments, prevents insularity, improves relations across cultural groups, and increases diversity."79

When "cultural survival” is ensconced as a legal norm, there is a tendency to deny the fluid and contested nature of culture and, instead, to see culture "as a thing that is possessed, or owned, by a largely homogenous and discrete, or bounded, group.”80 In particular, legal recognition of the "preservation of culture” tends to "do more than offer a means for cultural communities to regain a degree of control over their community and expressions.”81 Legally enforced cultural boundaries may work to enforce cultural orthodoxy and to reinforce the power of cultural leaders or spokespersons who suppress dissent. “'Law in the domains of culture’ threatens to freeze cultural groups in the status quo and dramatically shift the balance of power between members and leaders of cultural groups over the creation and control of cultural meanings.”82 When the treatment of human genetic information is at issue, the risks are apparent. Recognizing “control rights” by groups, in the name of “cultural preservation,” may simply serve to stifle cultural evolution and dissenting voices about the profound and potentially contested cultural, social, and medical issues that human genetics studies involve.

The recognition of the possibilities of repression of cultural dissent, false leadership, and
${ }^{79}$ Id. at 509.
${ }^{80} \mathrm{Id}$. at 510 (emphases deleted).
${ }^{81} I d$. at 503 .
${ }^{82} I d$. (footnote omitted) (emphasis deleted). 
other issues within groups that might assert genetic-control claims is obviously important. However, we must also remember that attempted repression of cultural change and dissent is not limited to the human groups that might assert genetic-control claims. All cultures - whether ethnically, politically, historically, religiously, or otherwise defined - are subject to the same evolutionary processes and the same desires on the parts of some to repress those processes. There is as much reason to be concerned about such risks when evaluating the professed cultural norms and positions of (for instance) traditional religious groups or local government leaders as there is when evaluating the professed cultural norms and positions of groups that make geneticcontrol claims. Intellectual and cultural ferment is simply a part of the human condition. That fact does not preclude our recognition of the claims of groups in other settings, and it should not - of itself - preclude the recognition of the claims of groups in this.

\section{(b) Conflict with Individual Choice}

Another serious objection to group rights in the genetic-control context is embedded in the general bias in Western jurisprudence against group rights with which we began. To the extent that rights are conferred upon groups or other collectivities, they are taken from individuals who are members of those groups. If we empower tribal governments, insular religious-group leaders, indigenous-group spokespersons, and others, we may enhance the autonomy of these groups, but it will be at the expense of the individual autonomy of their members.

That group exercise of authoritative powers entails loss of individual autonomy is 
undeniable. If the United States Congress decides whether human cloning is permissible, individuals are denied that choice. If a tribal government decides whether researchers shall be welcome on a reservation, individuals in that tribe are denied that choice. That group power is exercised in derogation of individual autonomy is tautologically true.

It is equally obvious, however, that we have no problem with governmental authority and group rule in a myriad of contexts. Philosophical hand-wringing over the inevitable loss of individual autonomy to group power is, thus, beside the point. In an organized society groups will, in some circumstances, prevail. The question, thus, is not whether individual autonomy should, in some idealized sense, be lost - but whether a particular group in a particular context should be afforded this power.

Let us proceed, then, to the genuine question: whether there are reasons why individualgroup conflict in the genetic-control context is particularly troubling. The most potent argument for individual control in this context is respect for the self-determination of patients. ${ }^{83}$ Since the genetics field involves disease - its detection, prevention, and cure, it is argued that individuals who are subject to those diseases have extremely strong moral claims to control in this field.

This is an important argument and must be carefully considered. It is, of course, possible to question the idea of the individual that this argument assumes. Even in the disease detection, prevention, and treatment context, the model of the supremacy of individual decisionmaking may not be shared by the persons who belong to groups who are asserting genetic-control claims. For individuals who are members of many societies, perspectives on the nature of disease, the

\footnotetext{
${ }^{83}$ See, e.g., E. Pellegrino, "Intersections of Western Biomedical Ethics and World Culture: Problematic and Possibility," Cambridge Quarterly of Healthcare Ethics 1 (1992): 191196, at 194.
} 
subject-investigator relationship, and the doctor-patient relationship do not mirror the Western (primarily American) idea of radical individualism. ${ }^{84}$ For persons in many cultures, the conflict between individual personhood and group norms in the genetic-control context may be far less than this objection supposes.

However, some conflict between individual desire for genetically related disease research and group decisionmaking can be presumed to be inevitable. In these circumstances, we must seriously ask: should collective determinations be binding upon individuals?

To analyze this question, we must distinguish the following situations:

- $\quad$ Groups whose memberships derive from the voluntary associations of individuals.

- $\quad$ Groups whose powers are governmental in nature.

- $\quad$ Groups whose powers are not governmental, but whose memberships are nonetheless involuntary or coerced on biological, practical, or other grounds.

If the situation involves a group of the first kind - i.e., a voluntary association of individuals - the conflict will most likely resolve itself. Any individual who is a member of a voluntary group, and who is unhappy with group decisions about genetic testing, use, or patenting, can simply eschew the group’s authority and seek participation or (non-participation) on terms and conditions of her own. A member of a cultural group, a religious group, or other voluntary group who does not wish to participate in genetic studies, or who wishes to participate

${ }^{84}$ See R. Levine, "Informed Consent: Some Challenges to the Universal Validity of the Western Model,” Law, Medicine \& Health Care 19 (1991): 207-213, at 209-210; Clinton, supra note 28, at 742 (For many Indians and many non-Westerners, "human beings are born into a closely linked and integrated network of family, kinship, social and political relations. One’s clan, kinship, and family identities are part of one's personal identity and one's rights and responsibilities exist only within the framework of such ... networks.”). 
in studies that the group rejects, is free - on her own - to do so. There may be social or cultural repercussions from this action; there may be individual hardships from group schism; there may be diminished opportunities for participation, if others decline - but none of these are peculiar to, or preventable by the denial of, the idea of group control.

If the situation involves a group of the second kind - i.e., a group with the powers of government - we have the other extreme. In this situation, membership criteria and the group's authority are established by law. This being so, the question of where individual rights end, and collective rights begin, has already been established. If the United States Congress forbids embryonic stem cell research - if a tribal government forbids the reservation testing of its members - those are the decisions of sovereignty. The fact that individual desires for research or treatment may be thwarted does not negate the collective values and collective rights on which these decisions are based. The idea that a "collective decision [in genetics studies] is not binding on individual community members" ${ }^{35}$ is therefore true if membership in the group is voluntary or other methods for individual exit exist. It is not true if the group is sovereign, and exercises those sovereign powers.

It is groups of the third kind that present the most difficult cases: groups whose powers are not governmental, but whose membership is nonetheless involuntary or coerced on biological, practical, or other grounds. Examples might include racial or ethnic groups, genetically linked family members, isolated populations whose contacts with researchers are controlled by leaders, and so on. In these cases, we have neither the powers of sovereignty nor the power of exit to answer the question. Rather, we must do so on other grounds.

\footnotetext{
${ }^{85}$ Sharp and Foster, supra note 8, at 43.
} 
In my view, resolution of these cases is necessarily contextual and dependent upon the strength of the competing interests involved. Of critical importance on the individual side is the ethic of individual disease detection, prevention, or treatment, or “patient status,” with which our consideration of individual-group conflict began. If the individual's dissent is due to immediate and tangible health concerns, it is difficult to imagine any group interest that could trump it. Thus, for instance, a family-group member has a right to seek genetic testing despite the desires of other family members for ignorance. ${ }^{86}$ Likewise, an indigenous group member would have a right (in theory, at least) to seek genetically inspired treatment for disease, despite the objections of her culture.

The balance of interests will shift as the connection between treatment of individual disease and the genetic project becomes more and more attenuated. Where, for instance, the genetic project is simply genetic sampling for anthropological research, or for possible discovery of diseases or cures, we cannot assume that group interests must always yield to individual desires. In each case, the strength of opposing interests must be considered. If the group fears stigmatization through genetic testing, the size of the group, the social identifiability of members of the group, and the social opprobrium attached to the genetically identified disease are relevant. There is much greater danger of stigmatization when the group is small, its members are readily identifiable, and the disease is devastating and incurable (e.g., the association of a tribal group with schizophrenia) than there is when the group encompasses millions of individuals, who are only generally identifiable, and the disease is common and curable (e.g., the association of a particular segment of the general population with particular kinds of cancer).

\footnotetext{
${ }^{86}$ See Laurie, supra note 56, at 48.
} 
Similarly, if the group interest is cultural in nature, different decisions will be justified if the cultural impact is slight, or if it is a case of serious cultural challenge, erosion, or substantial destruction. ${ }^{87}$

In short, the idea that the intrinsic merit of individual autonomy should preclude the exercise of genetic control powers by groups is overly simplistic. There is no reflexive, theoretical reason why individual decisionmaking should be favored in this context. Outcomes must depend upon the nature of group and individual relations, and the strength of the competing interests involved.

(c) “Common Heritage” Arguments

A final argument against group rights in the genetic-control context turns the theory of group rights upon itself. According to this argument, there is nothing wrong with group rights; indeed, utilitarian arguments (the "greatest good for the greatest number"), which implicitly underlie claims for group rights in this context, are certainly correct. Rather, the problem is that the applicable "group" is defined too narrowly. The "group" to whom rights should be afforded is not an indigenous group, or a family group, or an ethnic group; it is all of humankind.

This is a kind of "nesting” argument, but with broader implications. Groups who assert genetic control claims are obviously part of the larger human community. If members of those groups have genetic characteristics that would benefit disease research or other scientific study,

${ }^{87}$ See Barker, supra note 1 at 573, 598; T. Dougherty, "Group Rights to Cultural Survival: Intellectual Property Rights in Native American Cultural Symbols,” Columbia Human Rights Law Review 29 (1998): 235-400, at 369-372. 
there is (in the view of these critics) no reason to confer control on the particular sub-group involved. Their genetic materials - like all of the world's resources - should be utilized in a way to benefit all of humanity. To do less is to fail to recognize the common interests and needs of all humankind.

"Common heritage" arguments of this kind have been made in all genetics research projects ${ }^{88}$ A famous example can be found in an early Human Genome Diversity Project Summary Document, which described the "main value" of the project as "its enormous potential for illuminating our understanding of human history and identity." "There is a cultural imperative for us to ... use the extraordinary scientific power that has been created through the development of DNA technology ... for the benefit of all people ... ." ${ }^{89}$

This argument seems to advance a very simple challenge to the size of the net which we shall cast. For instance, in the famous case of Hagahai DNA sampling (and patenting), ${ }^{90}$ the question thus seems to be: who should be our "group of concern,” a Hagahai tribe of 293 members or all of those who will benefit from treatment of leukemia and degenerative

${ }^{88}$ They have also been raised in other contexts. See, e.g., J. Moustakas, "Group Rights in Cultural Property: Justifying Strict Inalienability,” Cornell Law Review 74 (1989): 1179-1227, at $1179 \mathrm{n} .2$ (discussing arguments that retention of plundered art is justified because it is "the common heritage of mankind”).

${ }^{89}$ Human Genome Diversity Project Summary Document, Porto Conte, Sardini Workshop, quoted in Grounds, supra note 74, at 65.

${ }^{90}$ In the early 1990s, NIH researchers found that some members of the Hagahai people of Papua New Guinea were infected with a previously unknown viral strain of HTLV-1. A cell line was developed from the human cells and a patent was sought. U.S. Patent no. 5,397,696, called the "Papua New Guinea human T-lymphotropic virus" was issued on March 14, 1995. The ensuing controversy is chronicled in Cultural Survival Quarterly 20 (1996): 37-41 (statements by Rural Advancement Foundation International (RAFI), Jonathan Friedlaender, Henry T. Greely, Dominic Sengi, and others). 
neurological diseases - potentially, all of humankind? ${ }^{91}$ Put this way, as a numbers game, the answer appears to be obvious.

However, we must think again. The idea that the interests of the many will always trump the interests of the few in this field is obviously untrue. Disease research and cures are undoubtedly critical human interests; yet they do not allow us to force individuals to undergo genetic testing, or allow us to conscript individuals for medical research. There are obviously limits to the use of a purely "utilitarian” calculus, in this sense, in the achievement of public health. Moreover, just as we cannot assume the supremacy of the many over the individual, so we cannot assume the supremacy of the many over smaller groups.

“Common heritage” arguments are, thus, a way to (falsely) assume the superiority of numbers. They are also a way to preclude, in a single stroke, the assertion of any interests by the opposing, smaller group. As Laurie Whitt has bitterly noted in a related context, "[t]he key first step is to declare that these indigenous genetic resources belong to everyone. As the 'common heritage of mankind' ..., they are 'not owned by any one people and are quite literaly a part of our human heritage from the past.' Thus, they are 'looked upon as a public good for which no payment is necessary or appropriate’”, and are ready for conversion into private property by those who would exploit them. ${ }^{92}$ "Common heritage” arguments are declarations of ownership, control, and exclusivity of interests. There must be more than a simple, unilateral declaration of appropriation to justify this - as opposed to some other - allocation of power.

\footnotetext{
${ }^{91}$ See Mead, supra note 6, at 50.

${ }^{92}$ Whitt, supra note 69, at 14-15 (footnotes omitted).
} 


\section{Conclusion}

The idea of group rights is generally regarded with deep skepticism in contemporary Western jurisprudence. It is generally assumed by liberal democratic governments and their supporters that moral value is rooted in the well-being of individuals, and that rights are a way to enforce this truth.

This general skepticism has pervaded the responses of many researchers and policymakers to the claims by groups to control over the collection, testing, and disposition of the genetic materials of their members. Because of a jurisprudential and ethical model which is rooted in individual concerns, the idea of group rights in this context has an aura of illegitimacy at the outset. We begin with a model that allows - only with great effort - the imagining of rights for groups.

It has been my contention in this essay that objections to group rights in this context are more a product of this model's unexamined bias than considered reasons. If one accepts the moral value of distinctively collective interests, there is no theoretical barrier to the recognition of morally grounded group rights. As a practical matter, group rights are cognizable in law, if lawmakers so desire. Indeed, lawmakers have so desired, in the recognition of rights of local and state governments, Indian tribes, families, religious and ethnic groups, and others. Evaluated analytically, none of the structural objections to group genetic-control rights (such as group affiliation, group agency, or “nesting”) nor the substantive objections (the alleged inappropriateness of “demes” or social groups as rights-carriers, the unjustified derogation of individual autonomy that group rights involve, or the needs of our "common heritage”) raised is 
as widely preclusive, or as unique to these group claims, as opponents commonly argue. There may be uncertainties in group genetic-control claims; there may be societal costs involved in their granting; but those uncertainties and costs are, in truth, no different in kind from those that we readily decide to tolerate or incur in other contexts.

Claims by groups to genetic control might be claims that we decide to honor or not, in view of all of the circumstances. However, those decisions should be informed and reasoned ones, and not simply the products of unexamined bias. 